MONIKA BARTNIK*

\title{
OdPOWIEDZIALNOŚć KARNA ZA NARAŻENIE NA ZARAŻENIE HIV I AIDS
}

Choroby zakaźne towarzyszą człowiekowi od zarania dziejów. Porównywalnie historia regulacji prawnych chorób zakaźnych oraz zakażeń jest zdecydowanie krótsza. Narażenie na zarażenie HIV i AIDS stanowi przestępstwo skierowane w najwyższe dobro, którym jest zdrowie i życie człowieka, i niewątpliwie należy do chorób cywilizacyjnych. Tak postawiona teza upoważnia do dokonania analizy przestępstwa narażenia na zarażenie w kontekście przepisów Kodeksu karnego ${ }^{1}$, a także przepisów pozakodeksowych. W niniejszym artykule podjęta zostanie problematyka odpowiedzialności karnej za przestępstwo narażenia na zarażenie HIV i AIDS.

W rozdziale II, zatytułowanym „Wolności, prawa i obowiązki człowieka i obywatela", w części stricte dotyczącej wolności i praw ekonomicznych, socjalnych i kulturalnych, Konstytucja Rzeczypospolitej Polskiej z dnia 2 kwietnia 1997 r. w art. 68 ust. 1 stanowi, iż: „Każdy ma prawo do ochrony zdrowia" ${ }^{2}$. Poprzez zapewnienie równego dostępu do świadczeń opieki zdrowotnej finansowanej ze środków publicznych ochrona ta gwarantowana jest wszystkim obywatelom niezależnie od ich sytuacji materialnej. Jak słusznie zauważa W. Skrzydło: „Obok tej generalnej zasady dotyczącej ochrony zdrowia, odnoszącej się do wszystkich, Konstytucja

* Dr nauk prawn., Instytut Prawa, Administracji i Zarządzania, Wydział Filologiczno-Historyczny, Akademia im. Jana Długosza w Częstochowie; e-mail: m.bartnik@ajd.czest. pl.

${ }^{1}$ Ustawa z dnia 6 czerwca 1997 r. - Kodeks karny, tekst jedn., Dz.U. z 2016 r. poz. 1137 z późn. zm. (dalej: k.k.).

${ }^{2}$ Konstytucja Rzeczypospolitej Polskiej z dnia 2 kwietnia 1997 r., Dz.U. Nr 78, poz. 483 z późn. zm. i sprost. (dalej: Konstytucja RP); zob. też: wyrok TK z 7 stycznia 2004 r., K 14/03, OTK-A 2004, nr 1, poz. 1; wyrok TK z 24 marca 1999 r., K 2/98, OTK 1999, nr 3, poz. 38. 
wprowadza jeszcze dodatkowe postanowienia dotyczące określonych grup ludności lub rodzaju chorób"3, nakładając obowiązek zapewnienia szczególnej opieki zdrowotnej: dzieciom, osobom starszym, osobom niepełnosprawnym, a także kobietom $\mathrm{w}$ ciąży. Tak skonstruowany przepis ustawy zasadniczej pozwala przyjąć, że prawo do ochrony zdrowia jest prawem powszechnym. To z kolei powoduje niemożność dokonywania jakichkolwiek wyłączeń podmiotowych. Również Trybunał Konstytucyjny stanął na stanowisku, że prawo do ochrony zdrowia jest prawem integralnie związanym $\mathrm{z}$ człowiekiem ${ }^{4}$. Osobny przepis ustawodawca poświęcił obowiązkowi zwalczania chorób epidemicznych (art. 68 ust. 4 Konstytucji RP). W ujęciu słownikowym pochodzący z języka greckiego

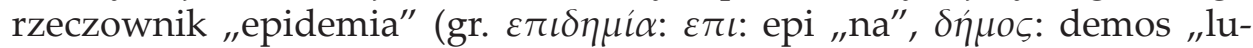
dzie”) oznacza pojawienie się i występowanie w określonym czasie (jednocześnie lub w krótkich odstępach czasu) i na określonym terenie przypadków zachorowań (głównie na choroby zakaźne) lub innych zjawisk związanych ze zdrowiem w liczbie większej niż oczekiwana ${ }^{5}$. Z uwagi na to, że prawo ma chronić społeczeństwo przed zakażeniami i chorobami zakaźnymi, rodzime ustawodawstwo zawiera szereg przepisów w tym zakresie, przy czym aktem normatywnym najpełniej regulującym omawianą problematykę jest ustawa $z$ dnia 5 grudnia $2008 \mathrm{r}$. o zapobieganiu oraz zwalczaniu zakażeń oraz chorób zakaźnych u ludzi ${ }^{6}$, która określa:

1) zasady i tryb zapobiegania oraz zwalczania zakażeń i chorób zakaźnych u ludzi, w tym zasady i tryb rozpoznawania i monitorowania sytuacji epidemiologicznej oraz podejmowania działań przeciwepidemicznych i zapobiegawczych w celu unieszkodliwienia źródeł zakażenia, przecięcia dróg szerzenia się zakażeń i chorób zakaźnych oraz uodpornienia osób podatnych na zakażenie;

2) zadania organów administracji publicznej w zakresie zapobiegania oraz zwalczania zakażeń i chorób zakaźnych u ludzi;

3) uprawnienia i obowiązki świadczeniodawców oraz osób przebywających na terytorium Rzeczypospolitej Polskiej w zakresie zapobiegania oraz zwalczania zakażeń i chorób zakaźnych u ludzi.

${ }^{3}$ W. Skrzydło, Komentarz do art. 68 Konstytucji Rzeczypospolitej Polskiej, [w:] W. Skrzydło, Konstytucja Rzeczypospolitej Polskiej. Komentarz, Lex/el (dostęp: 1.09.2017 r.).

${ }^{4}$ Postanowienie TK z dnia 20 lutego 2002 r., Ts 171/01, OTK 2002, nr 2B, poz. 168.

5 Zob. m.in.: M. Porta, A Dictionary of Epidemiology, Oxford 2008, s. 79; M. Szymczak, Słownik języka polskiego, t. I, Warszawa 1988, s. 548; J. Tokarski, Słownik wyrazów obcych, Warszawa 1980, s. 195.

${ }^{6}$ Ustawa z dnia 5 grudnia 2008 r. o zapobieganiu oraz zwalczaniu zakażeń oraz chorób zakaźnych u ludzi, tekst jedn., Dz.U. z 2016 r. poz. 1866 z późn. zm. 
Pojęcia choroby zakaźnej i zakażenia zostały zdefiniowane odpowiednio w przepisach art. 2 pkt 3 oraz art. 2 pkt 32 ustawy o zapobieganiu oraz zwalczaniu zakażeń oraz chorób zakaźnych u ludzi. W świetle przywołanych regulacji chorobą zakaźną jest choroba, która została wywołana przez biologiczny czynnik chorobotwórczy, natomiast zakażenie to wniknięcie do organizmu i rozwój w nim biologicznego czynnika chorobotwórczego, którym są posiadające zdolność wywoływania objawów chorobowych drobnoustroje komórkowe lub wytwarzane przez nie produkty, zewnętrzne i wewnętrzne pasożyty człowieka lub wytwarzane przez nie produkty, cząstki bezkomórkowe zdolne do replikacji lub przenoszenia materiału genetycznego, $\mathrm{w}$ tym zmodyfikowane genetycznie hodowle komórkowe lub wytwarzane przez nie produkty (art. 2 pkt 2 ustawy o zapobieganiu oraz zwalczaniu zakażeń oraz chorób zakaźnych u ludzi). Obok przywołanych definicji legalnych nie sposób pominąć również takich terminów jak: podejrzany o chorobę zakaźną, podejrzany o zakażenie, nosiciel. Zgodnie art. 2 ustawy o zapobieganiu oraz zwalczaniu zakażeń oraz chorób zakaźnych u ludzi podejrzanym o chorobę zakaźną jest osoba, u której występują objawy kliniczne lub odchylenia od stanu prawidłowego w badaniach dodatkowych, mogące wskazywać na chorobę zakaźną (pkt 20), podejrzanym o zakażenie - osoba, u której nie występują objawy zakażenia ani choroby zakaźnej, która miała styczność ze źródłem zakażenia, a charakter czynnika zakaźnego i okoliczności styczności uzasadniają podejrzenie zakażenia (pkt 21), natomiast nosicielem - osoba bez objawów choroby zakaźnej, w której organizmie bytują biologiczne czynniki chorobotwórcze, stanowiąca potencjalne źródło zakażenia innych osób (pkt 17).

Z kolei katalogi zakażeń i chorób zakaźnych pomieszczone zostały w załączniku „Wykaz zakażeń i chorób zakaźnych”, stanowiącym integralną część przywołanej ustawy; pkt 55 wymienia jako chorobę zakaźną AIDS oraz jako zakażenie HIV. Zakażonych HIV oraz chorych na AIDS dotyczą ogólne regulacje odnoszące się do zakażeń i chorób zakaźnych wymienionych w załączniku do przywołanej wyżej ustawy oraz w aktach normatywnych o randze podustawowej, do których należą m.in.:

1) rozporządzenie Ministra Zdrowia z dnia 10 lipca 2013 r. w sprawie zgłoszeń podejrzenia lub rozpoznania zakażenia, choroby zakaźnej lub zgonu z powodu zakażenia lub choroby zakaźnej”;

${ }^{7}$ Rozporządzenie Ministra Zdrowia z dnia 10 lipca 2013 r. w sprawie zgłoszeń podejrzenia lub rozpoznania zakażenia, choroby zakaźnej lub zgonu z powodu zakażenia lub choroby zakaźnej, Dz.U. z 2013 r. poz. 848. 
2) rozporządzenie Ministra Zdrowia z dnia 15 lutego 2011 r. w sprawie Krajowego Programu Zapobiegania Zakażeniom HIV i Zwalczania AIDS ${ }^{8}$;

3) rozporządzenie Ministra Zdrowia z dnia 9 października 2008 r. w sprawie wymagań, jakie powinien spełniać system zapewnienia jakości w bankach tkanek i komórek ${ }^{9}$;

4) rozporządzenie Ministra Pracy i Polityki Socjalnej z dnia 18 września 1998 r. w sprawie rodzajów schorzeń uzasadniających obniżenie wskaźnika zatrudnienia osób niepełnosprawnych oraz sposobu jego obniżania ${ }^{10}$.

W zakresie problematyki zakreślonej tematem niniejszego artykułu aktem prawnym o szczególnym charakterze jest ustawa $\mathrm{z}$ dnia 6 czerwca 1997 r. - Kodeks karny. Zgodnie z art. 161 § 1 k.k.: „Kto, wiedząc, że jest zarażony wirusem HIV, naraża bezpośrednio inną osobę na takie zarażenie, podlega karze pozbawienia wolności do lat 3 ".

W kontekście omawianej problematyki należy przypomnieć, że obowiązujące poprzednio kodeksy karne z 1932 r. ${ }^{11}$ i 1969 r. $^{12}$ nie wyodrębniały czynu zabronionego bezpośrednio związanego z wirusem $\mathrm{HIV}^{13}$. Dopiero obecnie obowiązujący Kodeks karny penalizuje zachowanie polegające na bezpośrednim narażeniu innej osoby na zarażenie wirusem HIV. Wprowadzenie do ustawy karnej nowego typu przestępstwa było swoistego rodzaju reakcją prawa karnego na problem związany z epidemiologicznym szerzeniem się wywołanej wirusem HIV nowej choroby $\mathrm{AIDS}^{14}$, zwanej potocznie dżumą XX wieku.

Human Immunodeficiency Virus (HIV) to retrowirus upośledzający układ odpornościowy człowieka aż do jego całkowitego wyniszczenia. Do zakażenia wirusem HIV dochodzi na skutek naruszenia ciągłości tkanek (używanie igieł i strzykawek, przeszczepy tkanek, transfuzje krwi), kontaktów seksualnych, przenoszony jest także z matki na dziecko w czasie

${ }^{8}$ Rozporządzenie Ministra Zdrowia z dnia 15 lutego 2011 r. w sprawie Krajowego Programu Zapobiegania Zakażeniom HIV i Zwalczania AIDS, Dz.U. Nr 44, poz. 227.

${ }_{9}$ Rozporządzenie Ministra Zdrowia z dnia 9 października 2008 r. w sprawie wymagań, jakie powinien spełniać system zapewnienia jakości w bankach tkanek i komórek, tekst jedn., Dz.U. z 2015 r. poz. 967.

${ }_{10}$ Rozporządzenie Ministra Pracy i Polityki Socjalnej z dnia 18 września 1998 r. w sprawie rodzajów schorzeń uzasadniających obniżenie wskaźnika zatrudnienia osób niepełnosprawnych oraz sposobu jego obniżania, Dz.U. Nr 124, poz. 820 z późn. zm.

${ }_{11}$ Rozporządzenie Prezydenta Rzeczypospolitej Polskiej z dnia 11 lipca 1932 r. - Kodeks karny, Dz.U. Nr 60, poz. 571 z późn. zm.

12 Ustawa z dnia 19 kwietnia 1969 r. - Kodeks karny, Dz.U. Nr 13, poz. 94 z późn. zm.

13 Zob. M. Derlatka, Zasadność kryminalizacji narażenia na zarażenie wirusem HIV, „Palestra" 2013, nr 7-8, s. 164.

${ }^{14}$ B. Michalski, Komentarz do art. 161 Kodeksu karnego, [w:] A. Wąsek (red.), Kodeks karny. Część szczególna. Komentarz do art. 117-221, t. 1, Warszawa 2006, s. 418. 
ciąży, porodu oraz karmienia piersią ${ }^{15}$. Z kolei AIDS (Acquired Immunodeficiency Syndrome lub Aacquired Immune Deficiency Syndrome) $\mathrm{w}$ świetle obowiązującej wiedzy medycznej stanowi czwartą (ostatnią) fazę rozwoju wirusa HIV i oznacza zespół nabytego upośledzenia odporności powodującego, że nawet najbardziej łagodne zakażenie bakteryjne może w krótkim czasie doprowadzić do śmierci chorego. W Polsce pierwszy przypadek zachorowania na AIDS odnotowano w $1987 \mathrm{r}^{16}$

Zgodnie z przepisem art. $161 \S 1$ k.k. do odpowiedzialności karnej za narażenie na zarażenie wirusem HIV może zostać pociągnięty każdy, kto wiedząc, że jest zarażony wirusem HIV, bezpośrednio naraża inną osobę na zarażenie nim. Specyficzna sytuacja powstaje, gdy do bezpośredniego narażenia na zarażenie wirusem HIV dochodzi podczas wykonywania czynności leczniczych. W układzie praw i obowiązków zarówno pacjentów, jak i personelu medycznego nie sposób nie wspomnieć również tych, które związane są z prawem do informacji, a więc zarówno z jej udzieleniem, jak i otrzymaniem. Każdy pacjent będący nosicielem wirusa HIV powinien udzielić personelowi medycznemu wyczerpujących informacji na ten temat. Również po stronie personelu medycznego istnieje obowiązek poinformowania pacjenta o fakcie bycia nosicielem wirusa HIV. Zarówno personel medyczny, jak i pacjent powinni być świadomi, że mają do czynienia z osobą zarażoną HIV, a także mieć wybór, czy chcą udzielać świadczeń (personel medyczny) albo być leczonym (pacjent) przez taką osobę, bo przecież zgodnie z art. $161 \S 1$ k.k. świadome i bezpośrednie narażenie innej osoby na zarażenie wirusem HIV stanowi podstawę do pociąnięcia sprawcy do odpowiedzialności karnej. Należy przy tym pamiętać, że omawiane przestępstwo ścigane jest na wniosek pokrzywdzonego (art. 161 $\S 3$ k.k.). Oznacza to, że organy ścigania, dysponując informacją o popełnionym przestępstwie, nie mogą wszcząć postępowania, dopóki wniosku o ściganie nie złoży sam pokrzywdzony. Zachowanie sprawcy spenalizowane $\mathrm{w}$ art. $161 \S 1$ k.k. - w porównaniu z przestępstwem narażenia na zarażenie chorobą weneryczną lub zakaźna, ciężką chorobą nieuleczalną lub realnie zagrażającą życiu (art. $161 \S 2$ k.k.) - zagrożone jest nieporównywalnie wysoką karą. O ile czyn zabroniony z art. $161 \S 1$ k.k. zagrożony jest karą do 3 lat pozbawienia wolności, o tyle w przypadku przestępstwa z art. $161 \S 2$ k.k. ustawodawca przewidział alternatywne zagrożenie karą grzywny, karą ograniczenia wolności albo karą pozbawienia wolności do

${ }_{15}$ Więcej na ten temat zob.: M. Rosińska, Epidemiologia HIV/AIDS ze szczególnym uwzględnieniem krajów rozwijajacych się, [w:] J. Cianciara, J. Juszczyk, Choroby zakaźne i pasożytnicze, Lublin 2007, s. 381.

16 B. Michalski, Komentarz do art. 161..., s. 418. 
roku. Bez ryzyka błędu należy stwierdzić, iż w wyniku kontaktów homoseksualnych, stosowania narkotyków w iniekcjach, kontaktów heteroseksualnych, zakażeń wertykalnych (matka-dziecko) czy też zakażeń jatrogennych pomiędzy osobami chorymi na AIDS a osobami zdrowymi, dochodzi do zarażenia wirusem HIV. Wobec tak postawionej tezy pojawia się pytanie, dlaczego ustawodawca surowiej karze osoby będące nosicielami wirusa HIV (art. $161 \S 1$ k.k.) niż osoby chore na AIDS (art. $161 \S 2$ k.k.) w sytuacji, gdy narażają one inne osoby na zarażenie wirusem HIV? Czy zatem bezpośrednie narażenie na „ciężką chorobę nieuleczalną", którą jest przecież AIDS, stanowi mniejsze zagrożenie dla zdrowia i życia człowieka niż bezpośrednie narażenie na zakażenie wirusem HIV? W tym miejscu powstaje pytanie o zasadność utrzymywania w ustawie karnej odrębnego przepisu penalizującego zachowanie sprawcy polegające na świadomym i bezpośrednim narażeniu na zarażenie wirusem HIV.

Jak informują statystki policyjne, przestępstwo z art. 161 k.k. (porównując z pozostałymi z rozdziału XIX przestępstw przeciwko życiu i zdrowiu) nie jest czynem popełnianym nadzwyczaj często, choć należy pamiętać o tzw. ciemnej liczbie, która w przypadku tego typu przestępstw może (choć nie musi) być zdecydowanie wyższa. Liczbę postępowań wszczętych oraz liczbę przestępstw stwierdzonych przedstawia poniższa tabela zawierająca dane z lat 2012-2016.

Tabela 1. Narażenie na chorobę wywołaną wirusem HIV, zakaźną lub weneryczną w latach 2012-2016

\begin{tabular}{|l|c|c|}
\hline Rok & $\begin{array}{l}\text { Liczba postępowań } \\
\text { wszczętych }\end{array}$ & $\begin{array}{l}\text { Liczba przestępstw } \\
\text { stwierdzonych }\end{array}$ \\
\hline 2016 & 25 & 5 \\
\hline 2015 & 29 & 9 \\
\hline 2014 & 35 & 14 \\
\hline 2013 & 27 & 12 \\
\hline 2012 & 23 & 7 \\
\hline
\end{tabular}

Źródło: http://statystyka.policja.pl/st/kodeks-karny/przestepstwa-przeciwko/63436,Narazenie-na-chorobe-wywolana-wirusem-HIV-zakazna-lub-weneryczna-art-161.html (dostęp: 1.09.2017 r.).

O tym, że przepis art. $161 \S 1$ k.k. nie jest często stosowany w praktyce, przesądza również liczba wydanych na jego podstawie wyroków skazujących: dwa skazania w 2012 r., cztery w 2011 r., cztery w 2010 r. ${ }^{17}$ Odmien-

17 Zob.: http://bip.ms.gov.pl/pl/dzialalnosc/statystyki (dostęp: 1.09.2017 r.). Wyroki skazujące wydane w roku 2010 dotyczą wyłącznie czynu zabronionego, którym jest bez- 
nie przedstawiają się statystyki udostępnione przez Państwowy Zakład Higieny Narodowego Instytutu Zdrowia Publicznego. Nawet pobieżna analiza danych z lat 2012-2016 pozwala stwierdzić, że liczba zakażeń HIV oraz zachorowań na AIDS w porównaniu z wszczętymi postępowaniami $\mathrm{z}$ art. $161 \S 1$ k.k. jest nieporównywalnie wysoka, co przedstawiają poniższe tabele.

Tabela 2. Zakażenia HIV i zachorowania na AIDS w Polsce w latach 2012-2016

\begin{tabular}{|c|c|c|c|}
\hline Rok & HIV & AIDS & Zgony chorych na AIDS \\
\hline 2016 & 1270 & 113 & 29 \\
\hline 2015 & 1273 & 129 & 40 \\
\hline 2014 & 1085 & 138 & 42 \\
\hline 2013 & 1258 & 214 & 61 \\
\hline 2012 & 1019 & 144 & 49 \\
\hline
\end{tabular}

Źródło: www.old.pzh.gov.pl/oldpage/epimeld (dostęp: 1.09.2017 r.).

Tabela 3. Liczba przypadków zarejestrowanych w 2016 r. wg płci

\begin{tabular}{|c|r|r|c|c|c|c|c|c|c|}
\hline \multirow{2}{*}{ Rok } & \multicolumn{4}{|c|}{ HIV } & \multicolumn{4}{|c|}{ AIDS } & \multicolumn{3}{|c|}{ Zgony chorych na AIDS } \\
\cline { 2 - 11 } & M & K & bd. & M & K & bd. & M & K & bd. \\
\hline 2016 & 1098 & 146 & 26 & 97 & 16 & - & 25 & 4 & - \\
\hline 2015 & 1071 & 184 & 18 & 90 & 39 & - & 29 & 11 & - \\
\hline 2014 & 899 & 172 & 14 & 112 & 26 & - & 36 & 6 & - \\
\hline 2013 & 1079 & 162 & 17 & 163 & 51 & - & 43 & 18 & - \\
\hline 2012 & 842 & 155 & 22 & 112 & 32 & - & 35 & 14 & - \\
\hline
\end{tabular}

Źródło: www.old.pzh.gov.pl/oldpage/epimeld (dostęp: 1.09.2017 r.).

Słowa kluczowe: zakażenie, zarażenie, odpowiedzialność, AIDS, HIV.

\section{Bibliografia}

Derlatka M., Zasadność kryminalizacji narażenia na zarażenie wirusem HIV, „Palestra" 2013, nr 7-8

Michalski B., Komentarz do art. 161 Kodeksu karnego, [w:] A. Wąsek (red.), Kodeks karny. Część szczególna. Komentarz do art. 117-221, t. 1, Warszawa 2006 Porta M., A Dictionary of Epidemiology, Oxford 2008

pośrednie narażenie innej osoby na zarażenie wirusem HIV, natomiast wyroki z lat 20112012 bezpośredniego narażenia innej osoby na zarażenie wirusem HIV, a także chorobą weneryczną lub zakaźną, ciężką chorobą nieuleczalną lub realnie zagrażającą życiu. 
Rosińska M., Epidemiologia HIVIAIDS ze szczególnym uwzględnieniem krajów rozwijających się, [w:] J. Cianciara, J. Juszczyk, Choroby zakaźne i pasożytnicze, Lublin 2007

Skrzydło W., Komentarz do art. 68 Konstytucji Rzeczypospolitej Polskiej, [w:] W. Skrzydło W., Konstytucja Rzeczypospolitej Polskiej. Komentarz, Lex/el (dostęp: 1.09.2017 r.)

Szymczak M., Stownik języka polskiego, t. I, Warszawa 1988

Tokarski J., Stownik wyrazów obcych, Warszawa 1980

\section{Źródła internetowe}

http://statystyka.policja.pl/st/kodeks-karny/przestepstwa-przeciwko/63436,Narazenie-na-chorobe-wywolana-wirusem-HIV-zakazna-lub-weneryczna-art-161.html (dostęp: 1.09.2017 r.)

http://bip.ms.gov.pl/pl/dzialalnosc/statystyki (dostęp: 1.09.2017 r.) wwwold. pzh.gov.pl/oldpage/epimeld (dostęp: 1.09.2017 r.)

\section{Orzecznictwo}

Wyrok TK z 7 stycznia 2004 r., K 14/03, OTK-A 2004, nr 1, poz. 1 Wyrok TK z 24 marca 1999 r., K 2/98, OTK 1999, nr 3, poz. 38

Postanowienie TK z 20 lutego 2002 r., Ts 171/01, OTK 2002, nr 2B, poz. 168

\section{CRIMINAL LIABILITY FOR EXPOSURE TO HIV AND AIDS}

\section{S u m m a r y}

The brief analysis of the criminal liability regulation for exposure to HIV and AIDS presents the view that instead of focusing on the punishment of already-penalized HIV carriers, $161 \S 1$ k.k. One should rather consider solutions that would make it impossible to transmit in most cases of fatal virus.

Key words: infection, infection, responsibility, AIDS, HIV.

\section{УГОЯОВНАЯ ОТВЕТСТВЕННОСТЬ ЗА ЗАРАЖЕНИЕ ВИЧ-ИНФЕКЦИЕЙ И СПИДОМ \\ P e 3 ю м е}

Представленный короткий анализ регулирования касательно угоиовной ответственности за заражение вирусом ВИЧ и болезнью СПИД, 
позволяет принять позицию, что вместо того, чтобы сосредоточиться на наказанию и такого „наказанного” уже носителя вируса ВИЧ, виновника преступления, со ст. 161 §1 УК, следовало бы скорее задуматься над решениями, которые призвели бы к невозможности переноса, в большинстве случаев, смертельного вируса.

Ключевые слова: инфекция, заражение, ответственность, СПИД, ВИЧ. 